\title{
A new frameshift mutation of the $\beta$-spectrin gene associated with hereditary spherocytosis
}

\author{
Dżamila M. Bogusławska ${ }^{1}$. Elżbieta Heger ${ }^{1}$ Beata Machnicka $^{1} \cdot$ Michal Skulski $^{3}$. \\ Kazimierz Kuliczkowski ${ }^{2}$. Aleksander F. Sikorski ${ }^{3}$
}

Received: 17 June 2016 / Accepted: 25 September 2016/Published online: 6 October 2016

(C) The Author(s) 2016. This article is published with open access at Springerlink.com

\section{Dear Editor,}

Hereditary spherocytosis (HS) is the most frequent congenital haemolytic anaemia in Caucasians. $\beta$-spectrin defects are typically inherited in an autosomal dominant manner with the clinical presentation of HS [5, 9]. We report on a new mutation in the SPTB gene (466insG) leading to a frameshift and a premature stop codon 29 codons downstream in the region encoding the C-terminal part of the dimerization domain. Most probably, instability of mutant mRNA results in spectrin deficiency and clinically moderate to serious HS.

The N-terminal region of the $\beta$-spectrin subunit consists of actin-binding domain and located downstream the dimerization domain consisting of the first two spectrin repeats. During our studies on HS cases in the population of Western Poland, we found a new mutation in a family

Electronic supplementary material The online version of this article (doi:10.1007/s00277-016-2838-0) contains supplementary material, which is available to authorized users.

Aleksander F. Sikorski

afsbc@ibmb.uni.wroc.pl

1 Department of Molecular Biology, Faculty of Biological Sciences, University of Zielona Góra, Szafrana 1, Zielona Góra 65-516, Poland

2 Department of Haematology, Blood Neoplasms and Bone Marrow Transplantation, Wroclaw Medical University, Wybrzeże Pasteura 4, Wrocław 50-367, Poland

3 Department of Cytobiochemistry, Biotechnology Faculty, University of Wrocław, F. Joliot-Curie 14a, 50-383 Wrocław, Poland with autosomal dominant HS [2-4]. Patients with moderate symptoms of the disease were recruited: mother $(\mathrm{C} 10$, splenectomized) and children (C14, C9), age ranged from 27 to 67 years. Diagnostic criteria for HS were based on typical features: spherocytes on peripheral blood smears, increased osmotic fragility, splenomegaly, increased bilirubin, reticulocytosis, anaemia and symptoms of gallstone disease (Supplemental Table I). The Ethics Committee of the Medical University of Wroclaw approved the study protocol. Informed consent was obtained from all patients and healthy individuals serving as a control before entering the protocol.

Molecular genetic analyses of the studied patients and the unaffected family members were performed. The nucleotide sequence of the ANK1, SPTB and SLC4A1 genes were amplified by PCR from genomic DNA. During DNA analysis of these genes, several common polymorphisms were encountered (Supplemental Table II). DNA sequencing revealed that all of the studied patients were heterozygous for novel mutation 466ins in the exon 11 of the $S P T B$ gene (Fig. 1a, b).

RBC membrane protein gel electrophoresis demonstrated deficiency of some membrane proteins: $\beta$-spectrin and ankyrin-1, thereby supporting the diagnosis of HS (data not shown). Immunoblotting of erythrocyte membrane ghosts from $\mathrm{C} 14$ and $\mathrm{C} 10$ patients with this mutation with antibody recognising an actin binding domain of $\beta$ spectrin [10] could not detect a truncated protein (data not shown), suggesting that this mutant transcript might be unstable. 
(a)

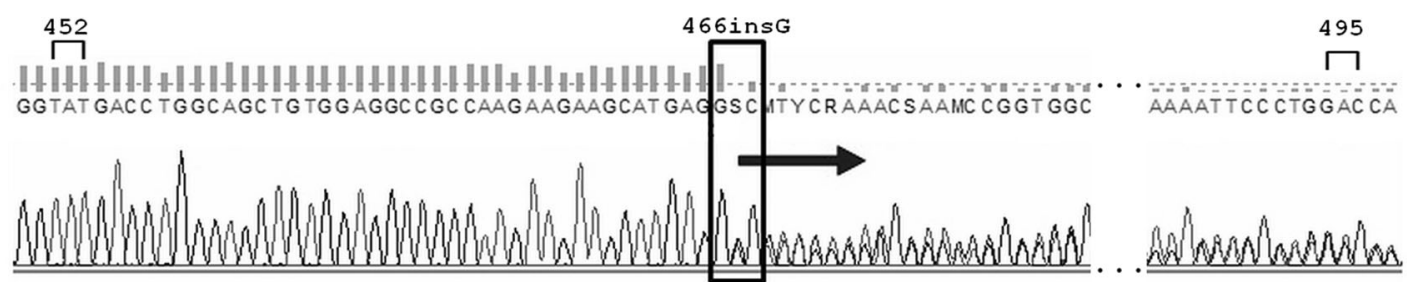

(b) wt
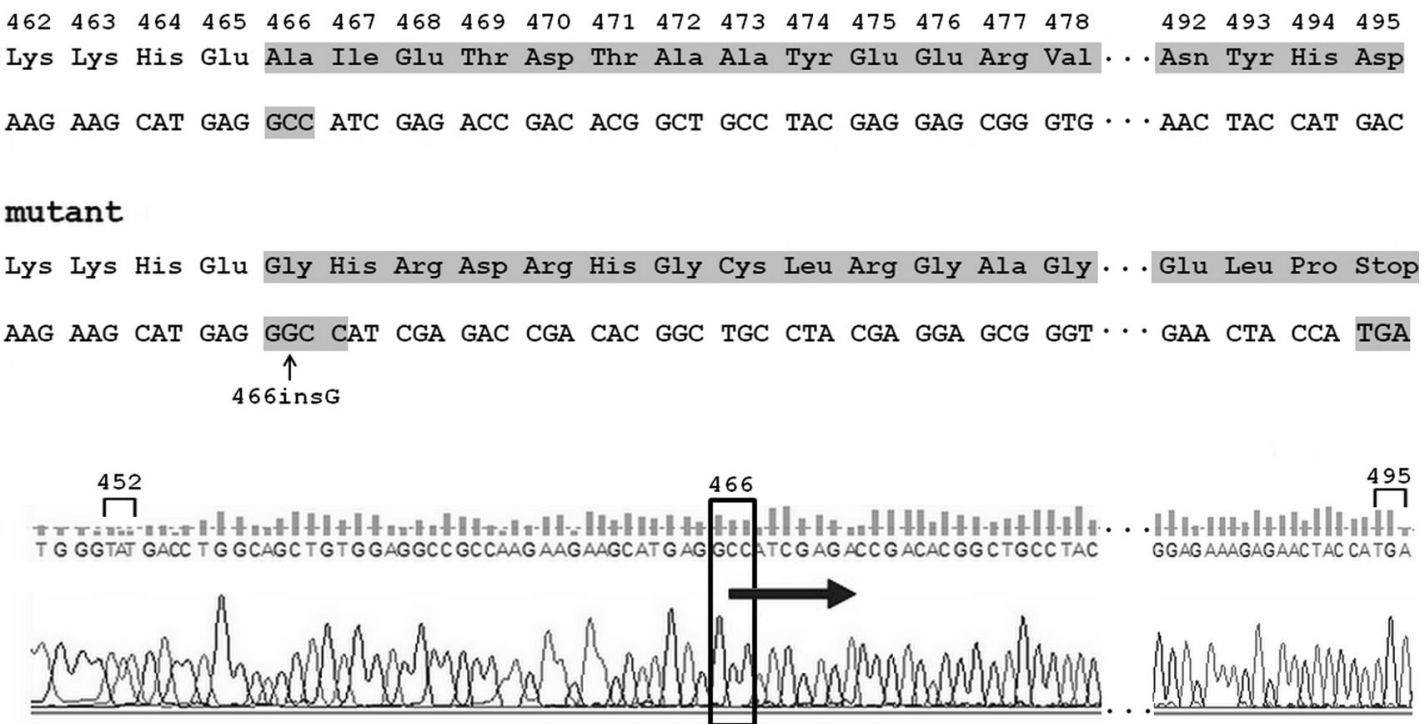

Fig. 1 Fragment of sequencing traces detected in the patient $\mathrm{C} 14$ showing: a A heterozygous single nucleotide 466insG in the exon 11 of the $S P T B$ gene (genomic DNA was used as a template). b 466insG

Next, we assessed the presence of the mutant mRNA transcripts. Loss of mutant allele in the cDNA in relation to the genomic DNA was observed (Fig. 1c), indicating that the mutant mRNA transcript was not present to detectable levels. Frameshift mutations of the SPTB gene associated with HS have been previously reported and in some cases the mutant mRNA could not be detected or was detected in decreased levels $[1,6-8]$. Also, the truncated protein could be observed in the erythrocyte or reticulocyte membrane [7]. As in the studied family the presence of mutated mRNA or truncated protein was not observed in the reticulocytes/erythrocytes, we conclude that in the studied family members probably monoallelic expression of the SPTB gene takes place which results in spectrin deficiency. This in consequence is a reason for a decreased surface density of the membrane skeleton and disturbed support of the membrane lipid bilayer and hereditary spherocytosis.

Acknowledgments DMB performed the molecular studies of the $A N K 1$ and SPTB genes (cDNA and gDNA), the erythrocyte membrane protein analysis, and wrote the manuscript. $\mathrm{EH}$ performed the molecular studies of the SLCAAI gene. BM performed RBC membrane protein analysis (immunoblotting analysis). MS performed the molecular studies of SPTB gene (cDNA). KK was responsible for the recruitment and clinical care of the patients and ethical aspects of the study. AFS leading to a frameshift and a premature stop codon 29 codons downstream. c Loss of mutant allele in the cDNA in relation to the genomic DNA (cDNA was used as a template)

supervised the study and did the final editing of the manuscript. This work was supported by a grant from the National Science Centre, Poland (Decision No. DEC-2012/05/B/NZ5/01464).

\section{Compliance with ethical standards}

Conflict of interest The authors declare that they have no conflict of interest.

Open Access This article is distributed under the terms of the Creative Commons Attribution 4.0 International License (http:// creativecommons.org/licenses/by/4.0/), which permits unrestricted use, distribution, and reproduction in any medium, provided you give appropriate credit to the original author(s) and the source, provide a link to the Creative Commons license, and indicate if changes were made.

\section{References}

1. Basseres DS, Tavares AC, Costa FF, Saad ST (2002) betaSpectrin Sao PauloII, a novel frameshift mutation of the betaspectrin gene associated with hereditary spherocytosis and instability of the mutant mRNA. Braz J Med Biol Res 35(8):921-925, doi:S0100-879X2002000800009 
2. Bogusławska DM, Heger E, Baldy-Chudzik K et al (2006) (AC)n microsatellite polymorphism and 14-nucleotide deletion in exon 42 ankyrin-1 gene in several families with hereditary spherocytosis in a population of South-Western Poland. Ann Hematol 85(5):337-339. doi:10.1007/s00277-006-0083-7

3. Bogusławska DM, Heger E, Chorzalska A et al (2004) Hereditary spherocytosis: identification of several HS families with ankyrin and band 3 deficiency in a population of southwestern Poland. Ann Hematol 83(1):28-33. doi:10.1007/s00277-003-0739-5

4. Bogusławska DM, Heger E, Listowski M et al (2014) A novel L1340P mutation in the ANK1 gene is associated with hereditary spherocytosis? Br J Haematol 167(2):269-271

5. Delaunay J (2007) The molecular basis of hereditary red cell membrane disorders. Blood Rev 21(1):1-20. doi:10.1016/j.blre.2006.03.005

6. Dhermy D, Galand C, Bournier O et al (1998) Hereditary spherocytosis with spectrin deficiency related to null mutations of the beta-spectrin gene. Blood Cells Mol Dis 24(2):251-261. doi:10.1006/bcmd.1998.0190

7. Hassoun H, Vassiliadis JN, Murray J et al (1996) Hereditary spherocytosis with spectrin deficiency due to an unstable truncated beta spectrin. Blood 87(6):2538-2545

8. Miraglia Del Giudice E, Lombardi C, Francesie M et al (1998) Frequent de novo monoallelic expression of $\beta$-spectrin gene (SPTB) in children with hereditary spherocytosis and isolated spectrin deficiency. Br J Haematol 101(2):251-254. doi:10.1046/j.1365-2141.1998.00688.x

9. Perrotta S, Gallagher PG, Mohandas N (2008) Hereditary spherocytosis. Lancet 372(9647):1411-1426. doi:10.1016/S0140-6736(08)61588-3

10. Toporkiewicz M, Grzybek M, Meissner J et al (2013) Release of an $\sim 55 \mathrm{kDa}$ fragment containing the actin-binding domain of $\beta$ spectrin by caspase- 8 during FND-induced apoptosis depends on the presence of protein 4.1. Arch Biochem Biophys 535(2):205213. doi:10.1016/j.abb.2013.03.009 